Louisiana State University

LSU Digital Commons

$12-1-2013$

\title{
Characterization of microsatellite loci for a threatened species, the King Rail, Rallus elegans, using a next-generation sequencing protocol
}

\author{
Carol L. Brackett \\ East Carolina University \\ James M. Maley \\ Louisiana State University \\ Robb T. Brumfield \\ Louisiana State University \\ Susan B. McRae \\ East Carolina University
}

Follow this and additional works at: https://digitalcommons.Isu.edu/biosci_pubs

\footnotetext{
Recommended Citation

Brackett, C., Maley, J., Brumfield, R., \& McRae, S. (2013). Characterization of microsatellite loci for a threatened species, the King Rail, Rallus elegans, using a next-generation sequencing protocol. Conservation Genetics Resources, 5 (4), 1189-1191. https://doi.org/10.1007/s12686-013-9999-0
}

This Letter to the Editor is brought to you for free and open access by the Department of Biological Sciences at LSU Digital Commons. It has been accepted for inclusion in Faculty Publications by an authorized administrator of LSU Digital Commons. For more information, please contact ir@lsu.edu. 


\title{
Characterization of microsatellite loci for a threatened species, the King Rail, Rallus elegans, using a next-generation sequencing protocol
}

\author{
Carol L. Brackett · James M. Maley • \\ Robb T. Brumfield · Susan B. McRae
}

Received: 24 May 2013/Accepted: 27 June 2013/Published online: 9 July 2013

(C) Springer Science+Business Media Dordrecht 2013

\begin{abstract}
The King Rail Rallus elegans (Audubon) has experienced population declines of $4.6 \%$ per year on average since the 1960s. Wetland loss, most severely affecting inland marshes, has significantly reduced this species' distribution to the coastal margins of its historic range. Polymorphic microsatellite markers were generated by 454 pyrosequencing of genomic DNA from King Rails, and Clapper Rails $R$. longirostris from Louisiana after AFLP enrichment and barcoding of restriction fragment cut sites across individuals. Of 1,419 microsatellite-containing sequences, 20 hypervariable microsatellite loci with up to 20 different alleles were identified at the alignment stage. We characterized nine loci, tested variability in 45 Atlantic coast King Rail samples, and detected 4-19 alleles per locus. Cross-species amplification revealed variability in the Virginia Rail, R. limicola, and Sora, Porzana carolina. These loci will be useful for studying secretive marsh rails, many of which are threatened or endangered.
\end{abstract}

Keywords King rail · Clapper rail $\cdot$ Rallus elegans · Rallus longirostris · Marshbird · Microsatellite · Pyrosequencing $\cdot$ AFLP enrichment $\cdot$ Barcoding

Electronic supplementary material The online version of this article (doi:10.1007/s12686-013-9999-0) contains supplementary material, which is available to authorized users.

C. L. Brackett · S. B. McRae $(\square)$

Department of Biology and Center for Biodiversity, East Carolina University, Greenville, NC 27858-4353, USA

e-mail: mcraes@ecu.edu

J. M. Maley · R. T. Brumfield

Museum of Natural Science, Department of Biological Sciences, Louisiana State University, 119 Foster Hall, Baton Rouge, LA 70803, USA
Genomic DNA was isolated from ten unrelated King Rails and ten unrelated Clapper Rails from southern Louisiana (Maley 2012). We generated AFLPs to reduce the genome and enrich markers. Each individual was barcoded for segments adjacent to restriction fragment cut sites. Each sample of genomic DNA was initially digested with EcoRI and $M s e \mathrm{I}$ cutters, and then ligated with a primer sequence. Digests were separated by electrophoresis. DNA fragments (350-450 bp) were cut from the gel, isolated and used in two rounds of PCR extending the primer by one base the first round, size selecting again, then adding two more bases and size selecting again. These steps were followed to obtain sequences from identical loci from all 20 individuals for the original purpose of identifying single nucleotide polymorphisms to distinguish King from Clapper Rails (Maley 2012).

Barcoded fragments were pyrosequenced on a Roche 454 using standard protocols (see McCormack et al. 2012). MSAT commander (Faircloth 2008) was used to screen the concatenated sequence data for microsatellite repeats. The selection process produced 1,419 DNA sequence fragments between 48 and 477 base pairs long containing di-, tetraand pentamer repeat microsatellites.

Alignments of 2-62 sequences $($ mean $=16.45)$ containing the same microsatellite motif revealed 20 different loci with repeat number variability of up to 20 alleles per locus among 20 individuals. Primer pairs were designed in unique flanking sequence for 15 loci. For another five, only one primer could be designed due to inadequate flanking sequence.

Primer pairs for each of the 15 loci were tested for amplification on King Rail samples collected from Mackay Island NWR, North Carolina (Brackett 2013). PCR was performed in $5 \mu \mathrm{L}$ total volume with $15-50 \mathrm{ng}$ template DNA, $20 \mathrm{mM}$ Tris-HCL (pH 8.4), $50 \mathrm{mM}$ KCL, 
Table 1 Characterization of polymorphic microsatellite loci for King Rails, including forward and reverse primers, specific annealing temperature $T_{a}\left({ }^{\circ} \mathrm{C}\right)$, number of individuals tested $(\mathrm{No})$, variability of alleles $\left(N_{A}\right)$, observed heterozygosity $\left(H_{O}\right)$, and expected heterozygosity $\left(H_{E}\right)$

\begin{tabular}{|c|c|c|c|c|c|c|c|c|c|c|}
\hline Locus & $\begin{array}{l}\text { GenBank } \\
\text { accession no. }\end{array}$ & $\begin{array}{l}\text { Repeat } \\
\text { motif }\end{array}$ & Primers sequences $\left(5^{\prime}-3^{\prime}\right)$ & $\begin{array}{l}\text { Allele size } \\
\text { range (bp) }\end{array}$ & $\begin{array}{l}\mathrm{MgCl}_{2} \\
(\mathrm{mM})\end{array}$ & $T_{a}\left({ }^{\circ} \mathrm{C}\right)$ & No & $N_{A}$ & $H_{O}$ & $H_{E}$ \\
\hline KiRa1a & KC990034 & CACAT & $\begin{array}{l}\text { F: AAGTGCTGGAGTGTGTCC } \\
\text { R: ACTGTACCTCATCAACACAGAG }\end{array}$ & $189-277$ & 10 & 59 & 42 & 14 & 0.881 & 0.884 \\
\hline KiRa5 & КC990035 & $\mathrm{TC}$ & $\begin{array}{l}\text { F: TGCTGCACTGAGACAACATCT } \\
\text { R: TGATCATGAGTAGAAGGAATAACCA }\end{array}$ & $304-331$ & 30 & 57 & 45 & 12 & 0.844 & 0.846 \\
\hline KiRa6 & КС990036 & $\mathrm{TC}$ & $\begin{array}{l}\text { F: CCTGCTGGAGGTACAAGGAG } \\
\text { R: ACAACGCAGGAGAAGGTGTT }\end{array}$ & $243-249$ & 30 & 59 & 45 & 4 & 0.600 & 0.602 \\
\hline KiRa7 & КC990037 & TAGA & $\begin{array}{l}\text { F: TACTCGTATGCCAGTGTTG } \\
\text { R: CAGAGATTATGTTCTCAATGACT }\end{array}$ & $144-192$ & 40 & 54 & 44 & 14 & 0.864 & 0.889 \\
\hline KiRa8a & КС990038 & ATGG & $\begin{array}{l}\text { F: GGCTGTGCAGAGAGGAAG } \\
\text { R: GTGACACTGATACAGTGTGCCT }\end{array}$ & $264-334$ & 40 & 60 & 42 & 19 & 0.952 & 0.919 \\
\hline KiRa9 & КC990039 & GT & $\begin{array}{l}\text { F: TGATCTGGGCAGGCTTCTAC } \\
\text { R: GTCGAATAATGGCAGCAATG }\end{array}$ & $165-209$ & 10 & 60 & 44 & 18 & 0.886 & 0.919 \\
\hline KiRa10 & КC990040 & CA & $\begin{array}{l}\text { F: CCAAGTACCATCTGCGAAGC } \\
\text { R: AACCCGAACGAGAGATGTGA }\end{array}$ & $124-146$ & 40 & 59 & 44 & 10 & 0.795 & 0.783 \\
\hline KiRa16 & КC990041 & TG & $\begin{array}{l}\text { F: CCAGGTGGAAACTCTGCATT } \\
\text { R: ACAGTTGTGATGTGGCTGGA }\end{array}$ & $265-304$ & 40 & 59 & 45 & 12 & 0.756 & 0.849 \\
\hline KiRa17a & КС 990042 & CA & $\begin{array}{l}\text { F: TTACCAGCAGCCAACTGTGA } \\
\text { R: AGTAGTGGTATCCTGGTGAGAGG }\end{array}$ & $234-268$ & 20 & 60 & 45 & 19 & 0.867 & 0.907 \\
\hline
\end{tabular}

$10-40 \mathrm{mM} \mathrm{MgCl} 2,0.2 \mathrm{mM}$ dNTPs, 0.5 pmol of each primer, and 0.05 Units of Taq DNA polymerase (Invitrogen). Reactions were carried out on a PTC-100 thermal cycler (MJ Research) using the following parameters: $94^{\circ}$ for 2 min, 25 cycles of $94^{\circ}$ for $30 \mathrm{~s}$, specified annealing temperature for $30 \mathrm{~s}$, and $72^{\circ}$ for $1 \mathrm{~min}$ followed by a final extension of $72^{\circ}$ for $5 \mathrm{~min}$. One primer of each pair was labeled with a colored fluorophore for visualization on an ABI 3130xl Genetic Analyzer. Alleles were sized using the program GeneMapper $^{\circledR}$ (Applied Biosystems).

Of 15 loci, nine were successfully optimized (Table 1). Among 45 unrelated Atlantic coast King Rails, no significant deviations from Hardy-Weinberg were detected. However, KiRa5 and KiRa10 showed significant linkage disequilibrium $(p=0.04)$. All loci were polymorphic in this population with a mean allele number of 13.56 and a mean observed heterozygosity of 0.8233 . Collectively, this panel of markers gives an estimated parentage exclusion probability of $5.91 \times 10^{-4}$ for first parent and $3.72 \times 10^{-9}$ for both parents.

Using the same PCR conditions, the primers crossamplified in the congeneric Virginia Rail and confamilial Sora (see Supplementary Materials). All but one locus were polymorphic in Virginia Rails; only one locus (KiRa6) failed to amplify in Sora. Alignments revealed variability also in Clapper Rails. Thus, these markers will be useful for studying a broad array of secretive rails, many of which are threatened or declining (Fleischer et al. 2009).

Next-generation sequencing using a mixture of genomic DNA from multiple individuals facilitated the rapid development of variable loci because we were able to detect variability at the alignment stage. Primer design could therefore be prioritized to those loci revealing high variability. Only $52.5 \%$ of our 1,419 microsatellite-containing contigs were more than $250 \mathrm{bp}$ in length, limiting our ability to design primer pairs for all microsatellite loci identified. Nevertheless, that variability could be assessed during the alignment stage significantly reduced the time and costs associated with purchasing and testing fluorescently labeled primers.

Acknowledgments We thank Mike Hoff and Jordan Black at Mackay Island NWR, J. Huner, L. Richard Jr., and P. Smith Jr., for access to private land, and Denise Mayer at ECU's Genomics Core Facility. Permits were provided by the USFWS (JMM, SBM), the Louisiana Department of Wildlife and Fisheries (JMM), the North Carolina Wildlife Resources Commission (SBM), Mackay Island NWR (SBM), and the USGS Bird Banding Lab (SBM). This research was supported by the Wilson's Society Paul A. Stewart Award (CLB), an ECU Graduate Scholarship (CLB), a Southeastern Region CESU Cooperative and Joint Venture Agreement (SBM), a USFWS Webless Migratory Game Bird Program Grant (SBM), and grants DEB0841729 (RTB), DEB-0956909 (RTB), and DEB-1110624 (RTB, JMM) from the NSF. 


\section{References}

Brackett CL (2013) Reproductive ecology and population genetics of the King Rail (Rallus elegans). MS thesis, East Carolina University, Greenville, NC

Faircloth BC (2008) MSATCOMMANDER: detection of microsatellite repeat arrays and automated, locus-specific primer design. Mol Ecol Resour 8:92-94

Fleischer RC, Fuller G, Ledig DB (2009) Genetic structure of endangered Clapper Rail (Rallus longirostris) populations in southern California. Conserv Biol 9:1234-1243
Maley J (2012) Ecological speciation of King Rails (Rallus elegans) and Clapper Rails (Rallus longirostris). Ph.D. dissertation, Louisiana State University, Baton Rouge

McCormack JE, Maley JM, Hird SM, Derryberry EP, Graves GR, Brumfield RT (2012) Next-generation sequencing reveals phylogeographic structure and a species tree for recent bird divergences. Mol Phylogenet Evol 62:397-406 